\title{
Impact of metazoan and protozoan grazers on bacterial biomass distribution in microcosm experiments
}

\author{
Klaus Jürgens ${ }^{1, *}$, Hartmut Arndt ${ }^{2}$, Heike Zimmermann ${ }^{3}$ \\ ${ }^{1}$ Max-Planck-Institut für Limnologie, PO Box 165, D-24302 Plön, Germany \\ ${ }^{2}$ Institut für Ökologie, Universität Greifswald, Schwedenhagen 6, D-18565 Kloster/Hiddensee, Germany \\ ${ }^{3}$ Institut für Hydrobiologie und Fischereiwissenschaft, Universität Hamburg, Zeiseweg 9, D-22765 Hamburg, Germany
}

\begin{abstract}
The interactions between different metazooplankters (cladocerans, rotifers, copepods), protozoans (ciliates, nanoflagellates) and bacteria (mixed lakewater culture) were examined in laboratory microcosm experiments. Growth of bacteria was stimulated in batch cultures by the addition of glucose. During $24 \mathrm{~h}$ experiments most of the bacterial production was consumed by nanoflagellates which achieved high growth rates. Moderate biomasses of copepods, rotifers or small cladocerans (Bosmina longirostris, Ceriodaphnia reticulata) had no or only weak effects on protozoan development. In contrast, Daphnia (D. galeata, D. magna) in higher densities consumed protozoans and bacteria simultaneously. Bacterial abundance was strongly reduced in all treatments but bacteria were either mainly consumed by protozoans (nanoflagellates) or by metazoans (Daphnia). This resulted in striking differences in the bacterial morphology of the remaining bacteria after $24 \mathrm{~h}$. A shift in bacterial size structure towards the appearance of large aggregates and long filaments correlated to predation by protozoans. These protozoan-resistant morphotypes dominated ungrazed bacterial biomass after $24 \mathrm{~h}$. When bacteria grew without predation or when Daphnia suppressed protozoan growth, the original bacterial size structure largely remained, and freely dispersed rods and cocci predominated. These model experiments illustrate the different impacts of metazoan and protozoan grazers which could both control bacterial production but produced a very different bacterial biomass distribution
\end{abstract}

KEY WORDS: Heterotrophic flagellates Ciliates - Bacteria - Metazoan grazing - Grazing resistance · Microbial food web

\section{INTRODUCTION}

Because free-living heterotrophic bacteria are an important component of planktonic systems (Cole et al. 1988), their regulation by nutrients and predation is one of the central topics in aquatic microbial ecology. The link between bacteria and their main grazers, heterotrophic nanoflagellates (HNF), is believed to have a controlling function on bacterial abundance, growth and community composition (Güde 1989, Sanders et al. 1992). Protozoans are themselves part of the pelagic food web and subject to predation by various other phagotrophs, especially metazooplankton.

•E-mail: juergens@mpil-ploen.mpg.de
Interactions between microbial and classical food webs need to be considered to increase our understanding of bacterial population dynamics and the regulating mechanisms within microbial food webs. Information about predation patterns, prey selection and feeding rates of metazooplankton on protozoans and bacteria is essential, and is now available for several zooplankton groups (Stoecker \& Capuzzo 1990, Arndt 1993, Jürgens 1994). The picture becomes more complex when feedback effects and cascading interactions between the different trophic levels are included. There is evidence that feedback mechanisms at the bacterial level, e.g. the development of grazing resistance, seem to be a widespread phenomenon and are especially important in more productive systems (Jürgens \& Güde 1994). 
Bacterial assemblages can change on a genotypic and phenotypic level due to the presence of predators, and intense predation by bacterivorous protozoans can result in an increased proportion of grazing-resistant bacteria (Güde 1979, Jürgens \& Güde 1994). High protozoan grazing pressure occurs only if nanoflagellates and small ciliates are not themselves controlled by predation. Evidence of a tightly coupled metazoanprotozoan-bacteria food chain has been observed in mesocosm experiments (Jürgens et al. 1994) where removal of filter-feeding metazooplankton resulted in a strong increase of phagotrophic protozoans and a concomitant shift in the bacterial community towards grazing-resistant forms (mainly long filaments). Field data from lake plankton also indicate that the presence of filter-feeding zooplankton has a pronounced effect on the bacteria-protozoan interactions and the development of grazing-resistant bacteria (Güde 1989, Jürgens \& Stolpe 1995).

Here we used an experimental system to mimic short-term interactions among the 3 trophic levels, bacteria, heterotrophic protozoans and metazooplankton. The experiments were designed (1) to examine the development of morphologically grazing-resistant bacteria after substrate enrichment and in the presence of heterotrophic protozoans and (2) to test whether the presence of metazooplankton has a profound effect on the protozoan-bacteria-interactions and if it prevents the development of grazing-resistant bacteria.

\section{MATERIAL AND METHODS}

For grazing experiments with metazooplankton different prey organisms (bacteria, algae, protozoans) were pooled to a 'food cocktail'. Concentrations, size and cell volume specifications of the prey organisms are given in Table 1. A mixed culture of bacteria (lake water inoculum), 3 species of nanoflagellates and Scenedesmus acutus were derived from continuous cultures; ciliates and metazooplankton were derived from batch stock cultures. The same food cocktail was used in another set of short-term grazing experiments to estimate feeding rates of metazooplankton on algae, protozoans and bacteria within a food mixture (Arndt et al. unpubl.). We estimated that of the final concentration of bacteria in the food cocktail approximately $>80 \%$ was from the chemostat culture, the rest was from the protozoan stock cultures. To reduce the chance of strongly deviating bacterial compositions in the different treatments, we added $1 \mu \mathrm{m}$ filtrate from all zooplankton cultures to the food cocktail.

In previous studies the bacterial culture from the chemostat exhibited no significant growth when transferred to batch culture (Jürgens 1992). Because an active shift in bacterial assemblages towards grazing resistance during predation seems to require substrate supply (Jürgens \& Güde 1994), we enhanced bacterial growth in the food cocktail by addition of glucose (30 $\mathrm{mg} \mathrm{l}^{-1}$ ). The mineral medium used for all stock cultures was a modified Chu-12 medium (Müller 1972) which supplied all mineral nutrients in excess of demands.

Metazooplankters were from the culture collection at the Max Planck Institute (courtesy of W. Lampert) or, in the case of Cyclops kolensis, collected in the field a few days before the experiment (Schierensee, northern Germany), Zooplankton biomass was estimated by measuring the body length under a stereomicroscope equipped with a half-automated image analysis system (Bioquandt Inc.) and calculating biomass with published length-weight regressions (Peters 1984). Information on size, concentration and biomass of metazooplankters is provided in Table 2. The different metazoan grazers were added to the food cocktail in $10 \mathrm{ml}$ (rotifers, Bosmina longirostris), $20 \mathrm{ml}$ (copepods, Ceriodaphnia recticulata), or $30 \mathrm{ml}$ (daphnids) glass vials which were fixed to a rotating wheel $(1 \mathrm{rpm})$ and incubated in a temperature-controlled room at $20^{\circ} \mathrm{C}$ in dim light. Samples were taken at the beginning and after $24 \mathrm{~h}$ and fixed with glutaraldehyde $(2 \%$ final concentration). A treatment which was kept without any metazooplankton served as a control. All treatments were run in 4 parallels except the experiments with $B$

Table 1. Specifications of prey organisms in the grazıng experiments

\begin{tabular}{|c|c|c|c|c|}
\hline Organism & Specifications & Culture conditions & $\begin{array}{l}\text { Approx. size } \\
(\mu \mathrm{m})\end{array}$ & $\begin{array}{l}\text { Mean volume } \\
\qquad\left(\mu \mathrm{m}^{3}\right)\end{array}$ \\
\hline Heterotrophic bacteria & Mixed lake-water culture & Chemostat, on glucose & $0.2-0.5 \times 0.8-1.2$ & 0.12 \\
\hline Scenedesmus acutus & Single cells & Chemostat, inorganic medium & $2.5-3 \times 12-18$ & 113 \\
\hline Spumella sp. & Bacterivorous chrysomonad & Chemostat, on bacteria & 3-5 (diameter) & 30 \\
\hline Bodo saltans & Bacterivorous kinetoplastid & Chemostat, on bacteria & $3-4 \times 5-6$ & 45 \\
\hline Paraphysomonas vestita & Omnivorous chrysomonad & Batch on bacteria & $7-10$ (diameter) & 250 \\
\hline Cyclidium sp. & Bacterivorous scuticociliate & Batch on bacteria & $4-6 \times 18-20$ & 420 \\
\hline Colpodasp. & Bacterivorous, holotrichous ciliate & Batch on bacteria & $25-30 \times 35-55$ & 9440 \\
\hline
\end{tabular}


Table 2. Mean body length, concentration and biomass of metazooplankton in the grazing experiments

\begin{tabular}{|lccc|}
\hline & $\begin{array}{c}\text { Body length } \\
\text { (mm) }\end{array}$ & $\begin{array}{c}\text { Concentration } \\
\text { (ind. } \text { l-1) }^{-1}\end{array}$ & $\begin{array}{c}\text { Biomass } \\
\text { (mg dry wt 1-1) }\end{array}$ \\
\hline Brachionus rubens & $0.15-0.18$ & 3181 & 0.42 \\
Brachionus angularts & 0.15 & 1797 & 0.16 \\
Cyclops kolensis & $0.81-0.82$ & 318 & 1.73 \\
Bosmina longirostris & $0.36-0.37$ & 1182 & 1.37 \\
Ceriodaphnia reticulata & $0.55-0.61$ & 371 & 1.44 \\
Daphnia galeata & $1.59-1.90$ & 182 & 3.46 \\
Daphnia magna & $2.13-2.52$ & 150 & 7.37 \\
\hline
\end{tabular}

ANOVA and post hoc comparisons of the means (Tukey's) longirostris and Brachionus rubens and B. angularis, where the number of experimental animals was sufficient for 1 trial only. These data will be shown but not included in a statistical analysis. Another control, which should provide estimates of bacterial growth in the absence of any predation, consisted of the mixed bacterial assemblage from the chemostat culture without any protozoans or metazoans.

Lugol-fixed protozoans and algae were counted with settling chambers in an inverted microscope. At least 50 ciliates, 200 flagellates and 200 algae were counted per sample. Bacteria were counted after DAPI staining and filtering on black polycarbonate filters in an epifluorescence microscope (Porter \& Feig 1980). The distribution of bacterial biomass into different morphotypes was also assessed from DAPI preparations (not performed for the experiment with Brachionus angularis). The biovolume of the freely dispersed bacteria was measured with an automated image analysis system (Schröder \& Krambeck 1991). Filamentous bacteria were counted at a lower magnification by examining stripes across the filter. Estimation of filamentous biomass was done by sizing filaments with the help of an ocular grid at a higher magnification. Only those parts of the filaments were included which crossed the ocular grid when passing along the stripes across the filter. The number of aggregated bacteria was estimated in the DAPI preparations when aggregates were small and single bacteria could still be differentiated (up to approx. 50 cells). Samples where larger bacterial clumps appeared were stained and counted twice. From the first DAPI preparation only the number of freely dispersed single cells was obtained. Then a subsample was sonicated (Branson Sonifier 250, 10 bursts of 3 s), which resulted in complete dispersion of the clumps without disruption of bacterial cells. The total number of bacteria was counted after a second DAPI preparation of this sonicated subsample. The difference between the 2 counts gives an estimate of the bacterial abundance in aggregates. Differences in HNF and ciliate numbers among the treatments were tested with 1-way $37 \times 10^{6}$ cells $\mathrm{ml}^{-1}$ after $24 \mathrm{~h}$. No bacterial proliferation could be observed in the food cocktail with the mixed protozoan assemblage (Fig. 1B), where protozoans were obviously able to control bacterial production and reduce bacterial density to low levels. Bacterial production was almost entirely channelled into protozoan growth. All flagellate and ciliate species increased in abundance but by far the strongest growth was observed for the kinetoplastid Bodo saltans, which increased by a factor of 4 (approx. growth rate: $0.08 \mathrm{~h}^{-1}$ ) and which might have been largely responsible for the consumption of bacterial production. The other bacterivorous protozoans, Spumella $\mathrm{sp}$. and the 2 ciliates Cyclidium sp. and Colpoda sp., increased as well although to a lesser extent than B. saltans. Strong growth of the omnivorous flagellate Paraphysomonas vestita (growth rate approx. $0.11 \mathrm{~h}^{-1}$ ) probably resulted from consumption of Scenedesmus because all Paraphysomonas observed at the end of the experiment had ingested algae inside the food vacuoles.

For a simplified comparison of the protozoan population changes in the different treatments, protozoans were pooled into heterotrophic nanoflagellates (HNF)

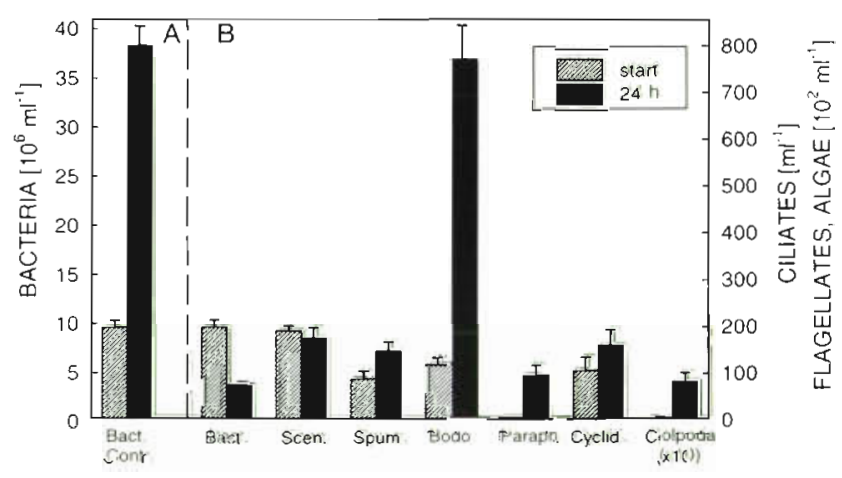

Fig. 1. Changes of bacteria, algae and protozoans during the $24 \mathrm{~h}$ experiments in the treatment without metazooplankton. (A) Bacteria in the predator-free control. (B) Organisms in the food cocktail. Error bars indicate standard deviation of the mean over 4 replicates 

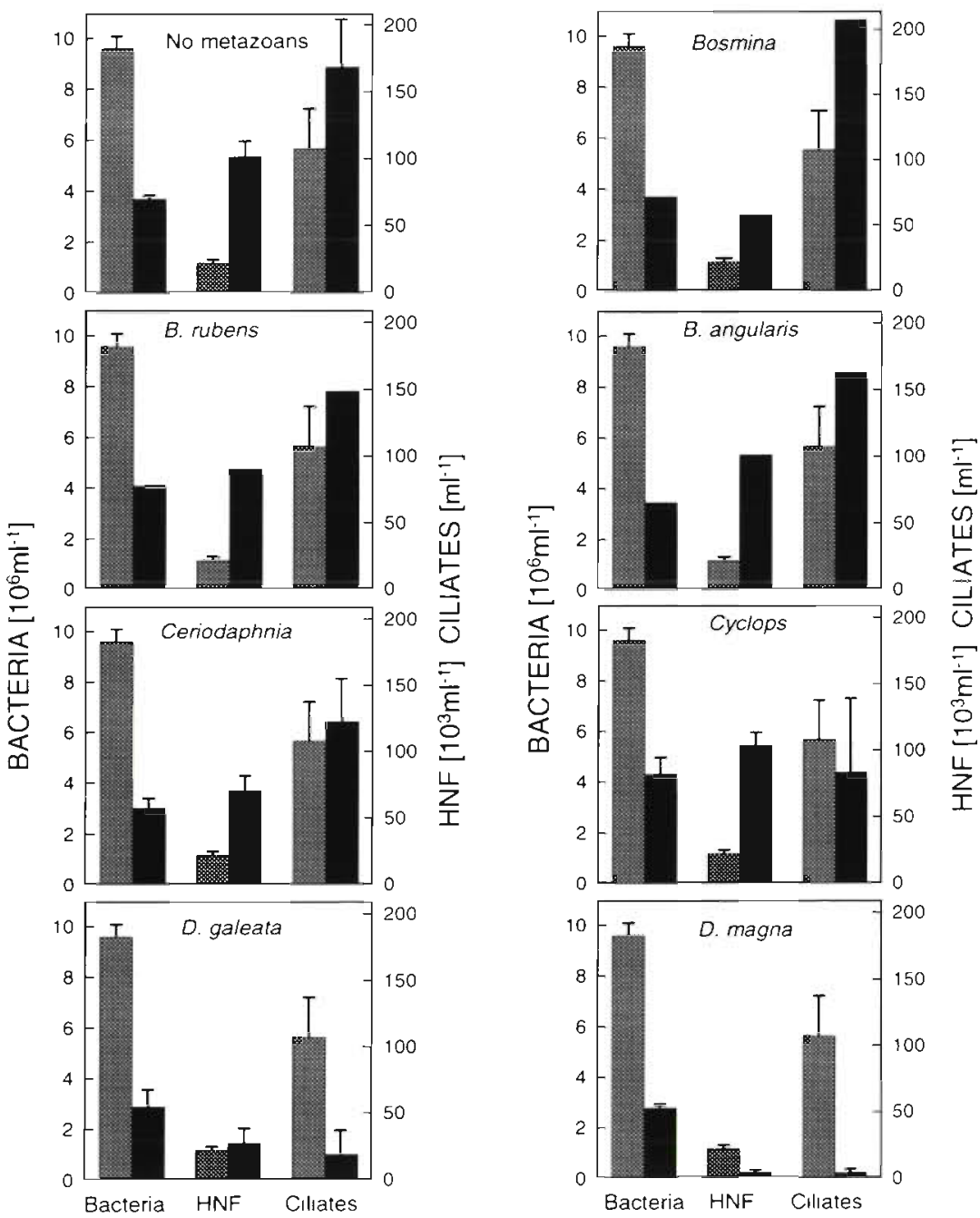

Fig. 2. Changes in cell numbers of bacteria, heterotrophic nanoflagellates (HNF) and ciliates in the different grazer treatments. For protozoan species composition see Table 1 Shaded bars: time zero; filled bars: after $24 \mathrm{~h}$. Error bars indicate standard deviation of the mean over 4 replicates and ciliates. Changes in population sizes of protozoans and bacteria are shown for the different treatments with and without metazoans in Fig. 2. Abundance of Scenedesmus was omitted in this figure because the algae were not relevant for the bacteria-protozoan interactions. The experiments with rotifers and Bosmina longirostris were not replicated but results are shown because the variability in the other treatments with replicates was relatively low at least for bacteria and HNF. The mean coefficient of variation (CV) was $12.3 \%$ for bacterial abundance, $30 \%$ for HNF and $63 \%$ for ciliates.

No obvious differences compared to the controls were visible in the treatments with rotifers (Brachionus rubens, B. angularis) and with Bosmina longirostris (because of missing replicates not statistically tested). No significant reduction of protozoans occurred with Ceriodaphnia recticulata, and with Cyclops kolensis only a marginally significant reduction of ciliates $(p=0.06)$ was registered. Strong effects were visible in the treatments with Daphnia galeata and D. magna, where protozoan growth was repressed and population levels highly significantly ( $\mathrm{p}<0.0001)$ reduced compared to the treatments without metazooplankton.

Bacteria were reduced in all treatments, with and without metazooplankton, down to $2-4 \times 10^{6}$ cells

Table 3. Abundance of different bacterial morphotypes at the beginning and after $24 \mathrm{~h}$ in the different treatments. Mean $( \pm \mathrm{SD}$ ) of 3 replicates (except for Brachionus and Bosmina)

\begin{tabular}{|c|c|c|c|c|c|}
\hline & & $\begin{array}{l}\text { Free bacteria } \\
\left(\times 10^{6} \mathrm{ml}^{-1}\right)\end{array}$ & $\begin{array}{c}\text { In aggregates } \\
\left(\times 10^{6} \mathrm{ml}^{-1}\right)\end{array}$ & $\begin{array}{l}\text { Filaments } \\
\left(\times 10^{3} \mathrm{ml}^{-1}\right)\end{array}$ & $\begin{array}{c}\text { Total bacteria } \\
\left(\times 10^{6} \mathrm{ml}^{-1}\right)\end{array}$ \\
\hline \multirow[t]{2}{*}{ Start } & Only bacteria & 9.98 & 0 & 0 & 9.98 \\
\hline & $\begin{array}{l}\text { Bacteria + protists } \\
\text { ('food cocktail') }\end{array}$ & $9.41 \pm 0.45$ & $0.16 \pm 0.05$ & $4.21 \pm 3.13$ & $9.58 \pm 1.05$ \\
\hline \multirow[t]{8}{*}{ After $24 \mathrm{~h}$} & Only bacteria & $37.62 \pm 1.10$ & $0.63 \pm 0.01$ & 0 & $37.93 \pm 1.32$ \\
\hline & Bacteria + protists & $0.66 \pm 0.04$ & $3.02 \pm 0.15$ & $14.75 \pm 2.18$ & $3.70 \pm 0.14$ \\
\hline & + Brachionus rubens & 0.64 & 2.16 & 14.96 & 2.82 \\
\hline & + Ceriodaphnia reticulata & $0.91 \pm 0.06$ & $2.06 \pm 0.38$ & $20.07 \pm 1.64$ & $2.99 \pm 0.41$ \\
\hline & + Bosmina longirostris & 1.34 & 1.72 & 189.63 & 3.25 \\
\hline & + Cyclops kolensis & $0.75 \pm 0.11$ & $3.52 \pm 0.77$ & $30.10 \pm 3.69$ & $4.30 \pm 0.66$ \\
\hline & + Daphnia galeata & $1.46 \pm 0.21$ & $1.42 \pm 0.61$ & $2.61 \pm 0.99$ & $2.88 \pm 0.69$ \\
\hline & + Daphnia magna & $1.95 \pm 0.06$ & $0.84 \pm 0.08$ & $1.61 \pm 0.38$ & $2.78 \pm 0.14$ \\
\hline
\end{tabular}


$\mathrm{ml}^{-1}$, which means that essentially all bacterial production was consumed and bacterial abundance reduced below the initial concentration level. The total number of bacteria was lowest in the 2 Daphnia treatments but differences were more striking when looking at the bacterial morphology of the ungrazed bacteria after $24 \mathrm{~h}$ (Table 3). Freely dispersed rods and cocci (termed 'free bacteria') dominated with more than $98 \%$ at the beginning of the experiments but were reduced in all trials without Daphnia to levels below $10^{6}$ cells $\mathrm{ml}^{-1}$ (then comprising 17 to $40 \%$ of the remaining bacteria). In these treatments the majority of remaining bacteria were concentrated in large aggregates, comprising several 100 to several 1000 densely packed cells (Fig. 3) An example of the size distribution of these aggregates, as derived from DAPI preparations, is shown in Fig. 4. The majority of the bacterial clumps had maximal diameters in the range 20 to $40 \mu \mathrm{m}$. Relatively high bacterial numbers ( 2 to $3.5 \times 10^{6}$ cells $\mathrm{ml}^{-1}$ ) were concentrated in these aggregates (Table 3). Only a few clumps appeared in the Daphnia trials and the majority of bacteria were still freely dispersed. In the nonDaphnia trials long filamentous bacteria also appeared, especially with Bosmina longirostris (Table 3).

The biomass composition of the bacterial community in these 3 different bacterial growth forms (rods and cocci, filaments, aggregates) and the total bacterial biovolume are shown in Fig. 5. At the beginning, and in the bacterial controls after $24 \mathrm{~h}$, nearly all biomass was contributed by freely dispersed, single bacterial cells. Strong differences were obvious between treatments where protozoans had developed and the Daphnia treatments in which protozoans were suppressed. Only with daphnids, D. magna and D. galeata, was the major portion of the bacterial biomass still in the form of freely dispersed rods and cocci. Aggregates and in one case filaments (Bosmina longirostris) dominated the bacterial biomass in all other treatments. Aggregates and filaments are not or only partially available for protozoans (Jürgens \& Güde 1994), which means that between 70 and $80 \%$ of bacterial biomass consisted of grazing-resistant bacteria at the end of the $24 \mathrm{~h}$ experiment.
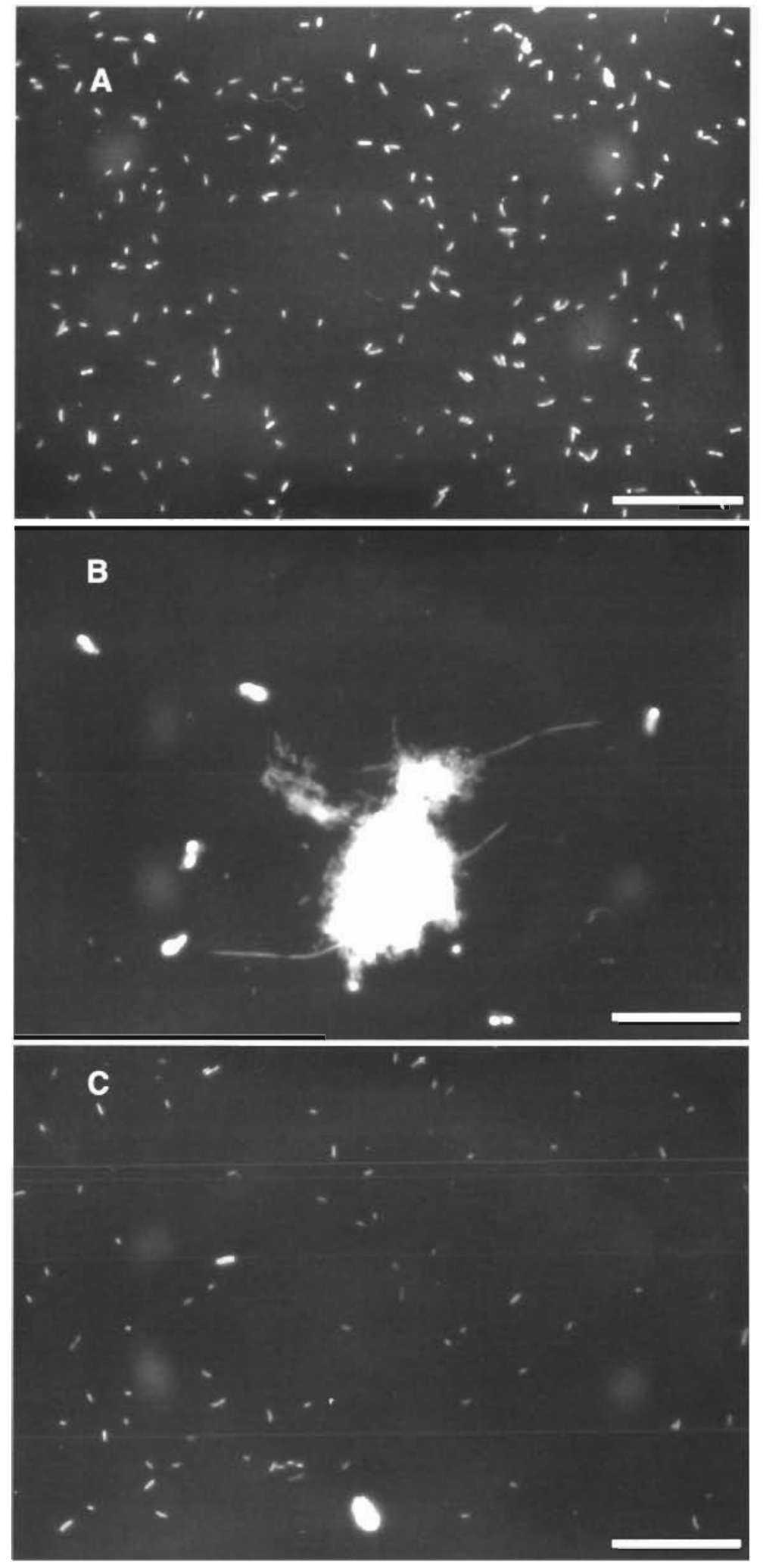

Fig. 3. Microphotographs of bacterial morphology after 24 h (DAPI-stained preparations). (A) With bacteria only; (B) bacteria and protozoans;

(C) bacteria, protozoans and Daphnia magna. Scale bars $=10 \mu \mathrm{m}$ 


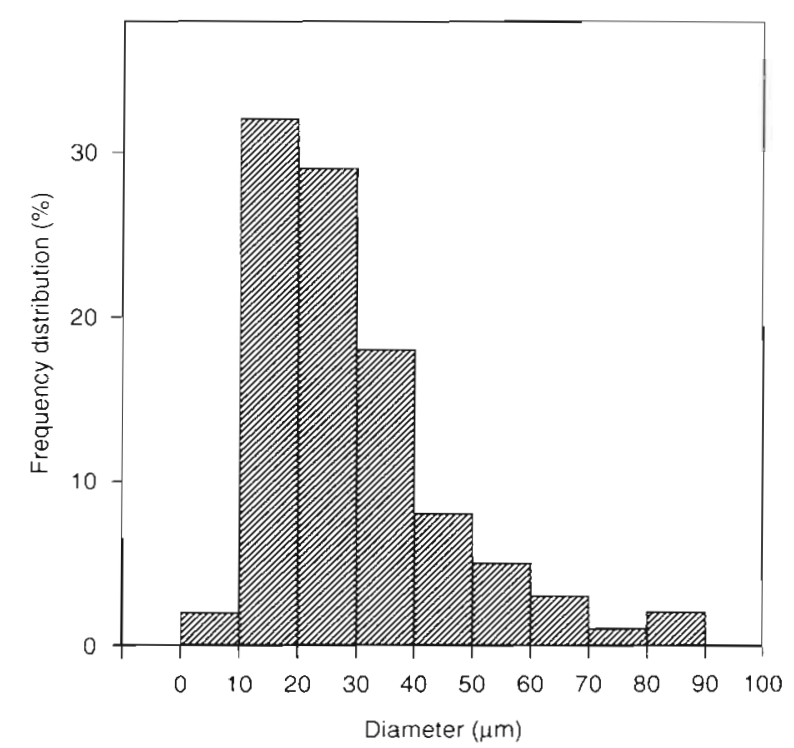

Fig. 4. Example of size distribution of bacterial aggregates (from control without metazoans): frequency distribution of the longest linear diameter of bacterial aggregates, as measured in DAPI preparations

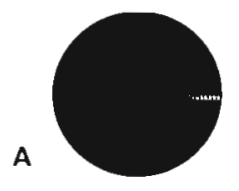

bacteria + protists (start) $(8.2 \pm 0.9)$

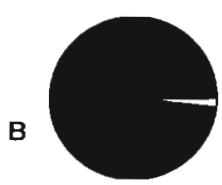

only bacteria $\langle 32.5 \pm 0.9\rangle$

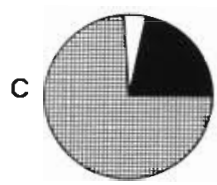

B. rubens (2.5)

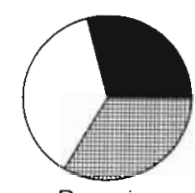

Bosmina

(3.9)

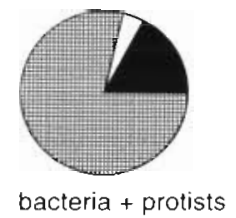

$(3.3 \pm 0.2)$

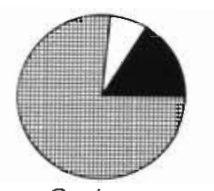

Cyclops

$(3.9 \pm 0.8)$

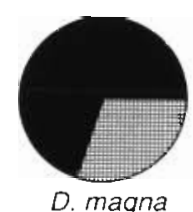

$(2.4 \pm 0.1)$

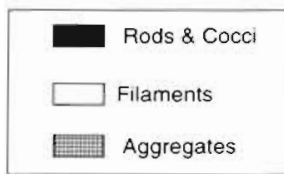

Aggregates

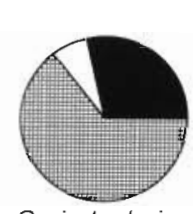

Ceriodaphnia $(2.7 \pm 0.4)$

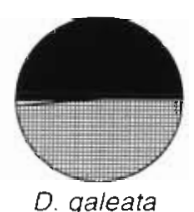

$(2.5 \pm 0.7)$

Fig. 5. Morphological composition of the bacterial biomass in the different treatments. (A) Food cocktail at the start of the experiment. (B) Controls without metazoans after $24 \mathrm{~h}$. (C) Metazoan treatments. Contribution of 3 different bacterial morphotypes (freely dispersed rods and cocci, filaments, aggregates) to bacterial biomass (in \%). Numbers below figures refer to total bacterial biovolume (n $10^{5} \mu \mathrm{m}^{3} \mathrm{ml}^{-1}$ )

\section{DISCUSSION}

Non- or slow-growing prey organisms are a prerequisite when measuring food selection and feeding rates. In contrast, the addition of glucose in the present study as a carbon substrate for the bacteria produced a dynamic system with strong growth for all heterotrophic microorganisms and enabled the occurrence of rapid feedback mechanisms on the bacterial level. Our goal was not to measure carbon flows or to compare feeding rates between the different compartments: instead, we wanted to illustrate how trophic interactions between bacteria, heterotrophic protozoans and metazoans can affect the development of grazingresistant bacteria.

This study shows that an active community of bacterivorous protozoans is able to track and control even high bacterial production, as occurred after the glucose addition. Except in the protozoan-free controls the bacterial productivity was not visible because it was directly channelled into production of protozoan biomass, especially to that of HNF. The efficient consumption of bacteria has been shown previously in grazing experiments with the same HNF species and the mixed bacterial chemostat culture (Jurgens 1992). A major difference between our dynamic system and batch grazing experiments with non-growing bacteria was visible in the phenotypic appearance of the bacterial assemblage and the final concentration of bacteria. Non-growing, stationary bacteria are usually reduced by HNF grazing down to levels of 2 to $5 \times 10^{5} \mathrm{ml}^{-1}$ without the appearance of peculiar bacterial morphotypes (Jürgens 1992). Here, in contrast, HNF were grazing on a growing bacterial assemblage. The final bacterial concentration was 1 order of magnitude higher than in the latter case due to the development of large aggregates and long filaments. These cells comprised the major part of the bacterial biomass at the end of the 24 h experiment and such complex morphotypes are abviously not, or only partly, susceptible to protozoan grazers.

Because undefined bacteria were introduced together with metazoan and protozoan cultures into the food cocktail and because we did not have a controlled genotypic composition of the bacteria, we have to be careful in the interpretation of the results. However, we think that our experimental design produced a comparable bacterial species composition in the different treatments with and without metazoans, therefore allowing a comparison of the results. The development of grazing-resistant growth forms in our experiments was not purely a result of negative selection, i.e. these forms remained whereas freely dispersed cells were removed. The most prominent grazing-resistant bacterial morphotypes were the aggregates which consis- 
tently developed in all treatments with high protozoan grazing pressure. The appearance of bacterial aggregates within the $24 \mathrm{~h}$ experiments was a de novo particle synthesis and seemed to be entirely dependent on the presence of bacterivorous protozoans. When protozoans were not present (bacterial controls) or when they were suppressed (with daphnids), aggregation was largely reduced.

If we accept that the process of bacterial aggregation is purely a result of protozoan grazing pressure, the presence of metazooplankton should prevent this process if they are able to control protozoan abundance. In feeding experiments with different zooplankton species it was shown that all the metazooplankter used here, except cyclopoids, are more or less similarly efficient consumers of heterotrophic nanoflagellates (Jürgens et al. 1996). However, in our experimental system described here, only Daphnia galeata and $D$. magna were able to suppress growth of the protozoan community. We assume that the biomass of the smaller zooplankter was not sufficient to control protozoans which grew at very high rates.

The general impact of daphnids on microbial components involves some special features, i.e. they are efficient consumers of larger bacteria and a wide range of protozoans (Jürgens 1994), and community filtration rates of Daphnia can be very high (e.g. Lampert 1988). Two mechanisms can prevent the development of grazing-resistant bacterial growth forms when daphnids are present: suppression of protozoan grazing pressure on bacteria and consumption of complex bacterial growth forms (Güde 1989). We should expect the same effect, i.e. the prevention of bacterial aggregates, when other filter-feeders (e.g. Bosmina, Ceriodaphnia) are present in high numbers. But the zooplankton densities chosen were related to maximal reported abundances in eutrophic lakes. For the smaller zooplankton species this was obviously insufficient to control the strong HNF growth in the experiments.

It has been demonstrated previously in laboratory microcosm experiments that grazing by protozoans can result in the development of complex bacterial growth forms (Güde 1979, 1982, Caron et al. 1988). This can be due to genotypic changes of the bacterial assemblage towards grazing-resistant forms (Güde 1979). But bacterial strains have also been identified which can change their phenotype in the presence of protozoans from growth in small, single cells towards growth in filaments (Shikano et al. 1990) or in aggregates (Güde 1982). Changes in surface structures and hydrophobicity (Rosenberg \& Kjelleberg 1986) and the production of extracellular polymers (Geesey 1982) can be involved in the adhesion and aggregation process.
Enhancement of bacterial aggregate formation by protozoan grazers might have been involved in many decomposition studies where microbial colonisation and succession on a natural DOC source was followed (e.g. Biddanda 1985. Biddanda \& Pomeroy 1988, Alber \& Valiela 1994). It has been noted that the aggregates which appeared in these experiments consisted to a large degree of bacteria but also of extracellular polymers (Alber \& Valiela 1994). In the majority of studies which examined aggregate production in microcosm experiments, bacteria were considered as the catalysing agents. However, protozoan-free controls were generally missing in these experiments and thus we cannot assess to what extent grazing by bacterivores was necessary for the aggregate formation.

Shifts in the bacterial community structure towards grazing-resistant forms can regularly be observed in natural systems but to a less drastic extent than in experimental microcosms. The effect of increased grazer populations on the size distribution of bacterioplankton is well known, with an increased proportion of very small and very large cells (Simek \& Chrzanowski 1992, Pernthaler et al. 1996). The tendency for aggregates and filaments to develop has been seen in freshwater plankton during population maxima of HNF (Güde 1989, Jürgens \& Stolpe 1995). It seems that complex bacterial morphologies are more abundant in more productive systems such as sediments, hypertrophic ponds, detrital aggregates, and sewage treatment plants (Jürgens \& Güde 1994, Sommaruga \& Psenner 1995), which is in accordance with the assumption that these forms can predominate when competition for substrates is low (Güde 1989).

Bacteria-protozoan interactions are known to play an important role in the decomposition of organic matter (Fenchel \& Harrison 1976, Sherr et al. 1982) and grazing-induced shifts in bacterial communities certainly influence the carbon fluxes. A combination of well-defined laboratory studies with field experiments at different scales is necessary to gain more insight in to the role of feedback mechanisms in bacterial populations. Concerning the situation in planktonic systems, it is becoming increasingly clear that interactions between all trophic levels have to be included for a comprehensive understanding of regulating mechanisms and population dynamics in bacterioplankton.

Acknowledgements. This work was supported by a research fellowship from the Humboldt Foundation to H.A. We are very thankful for encouragement and support by $W$. Lampert. Thanks are due to $\mathrm{N}$. Zehrbach for linguistic improvements and 3 anonymous reviewers for helpful comments on the manuscript. 


\section{LITERATURE CITED}

Alber M. Valiela I (1994) Production of microbial organic aggregates from macrophyte-derived dissolved organic material. Limnol Oceanogr 39:37-50

Arndt H (1993) Rotifers as predators on components of the microbial web (bacteria, heterotrophic flagellates, ciliates) - a review. Hydrobiologia 255/256:231-246

Biddanda BA (1985) Microbial synthesis of macroparticulate matter. Mar Ecol Prog Ser 20:241-251

Biddanda BA, Pomeroy LR (1988) Microbial aggregation and degradation of phytoplankton-derived detritus in seawater. I. Microbial succession. Mar Ecol Prog Ser 42:79-88

Caron DA, Goldman JC, Dennett MR (1988) Experimental demonstration of the roles of bacteria and bacterivorous protozoa in plankton nutrient cycles. Hydrobiologia 159: $27-40$

Cole JJ, Findlay S, Pace ML (1988) Bacterial production in fresh and saltwater ecosystems: a cross-system overview Mar Ecol Prog Ser 43:1-10

Fenchel T, Harrison P (1976) The significance of bacterial grazing and mineral cycling for the decomposition of par ticulate detritus. In: Anderson JM, Macfadyen A (eds) The role of terrestrial and aquatic organisms in decomposition processes. Blackwell, Oxford, p 285-299

Geesey GG (1982) Microbial exopolymers: ecological and economic considerations. ASM News 48:9-14

Güde H (1979) Grazing by protozoa as selection factor for activated sludge bacteria. Microb Ecol 5:225-237

Güde $H$ (1982) Interactions between floc-forming and nonfloc-forming bacterial populations from activated sludge. Curr Microbiol 7:347-350

Güde H (1989) The role of grazing on bacteria in plankton succession. In: Sommer U (ed) Plankton ecology. Succession in plankton communities. Springer Verlag, Berlin, p $337-364$

Jürgens K (1992) Is there plenty of food for bacterivorous flagellates in eutrophic waters? Arch Hydrobiol Beih Ergebn Limnol 37:195-205

Jürgens K (1994) The impact of Daphnia on microbial food webs - a review. Mar Microb Food Webs 8:295-324

Jürgens $K_{1}$ Arndt $H$, Rothhaupt $K O$ (1994) Zooplanktonmediated changes of bacterial community structure Microb Ecol 27:27-42

Jürgens K, Gude H (1994) The potential importance of grazing-resistant bacteria in planktonic systems. Mar Ecol Prog Ser 112:169-188

Responsible Subject Editor: K. Simek, Ceské Budějovice, Czech Republic
Jürgens K. Stolpe G (1995) Seasonal dynamics of crustacean zooplankton, heterotrophic nanoflagellates and bacteria in a shallow, eutrophic lake. Freshwat Biol 33:27-38

Jürgens K, Wirkham SA, Rothhaupt KO, Santer B (1996) Feeding rates of macro- and microzooplankton on heterotrophic nanoflagellates. Limnol Oceanogr 421833-1839

Lampert W (1988) The relationship between zooplankton biomass and grazing: a review. Limnologica 19:11-20

Müller H (1972) Wachstum und Phosphatbedarf von Nitzschia actinastroides (Lemm.) v. Goor in statischer und homokontinuierlicher Kultur unter Phosphatlimitierung. Arch Hydrobiol Suppl 38:399-484

Pernthaler J, Sattler B, Simek $K_{1}$ Schwarzenbacher A, Psenner R (1996) Top-down effects on the size-biomass distribution of a freshwater bacterioplankton community. Aquat Microb Ecol 3:255-263

Peters RH (1984) Methods for the study of feeding, grazing and assimilation by zooplankton. In: Downing JA, Rigler FH (eds) A manual on methods for the assessment of secondary production in freshwaters. IBP Handbook No. 17. Blackwell, Oxford, p 336-412

Porter KG, Feig YS (1980) The use of DA.PI for identifying and counting aquatic microflora. Limnol Oceanogr 25:943-947

Rosenberg $M$, Kjelleberg $S$ (1986) Hydrophobic interactions: role on bacterial adhesion. Adv Microb Ecol 9:353-393

Sanders RW, Caron DA, Berninger UG (1992) Relationships between bacteria and heterotrophic nanoplankton in marine and fresh waters: an inter-ecosystem comparison. Mar Ecol Prog Ser 86:1-14

Schröder D, Krambeck HJ (1991) Advances in digital image analysis of bacterioplankton with epifluorescence microscopy. Verh Int Verein Limnol 24:2601-2604

Sherr BF, Sherr EB, Berman T (1982) Decomposition of organic detritus: a selective role for microflagellate protozoa. Limnol Oceanogr 27:765-769

Shikano S, Luckinbill LS, Kurihara Y (1990) Changes of traits in a bacterial population associated with protozoal predation. Microb Ecol 20:75-84

Simek K, Chrzanowski TH (1992) Direct and indirect evidence of size-selective grazing on pelagic bacteria by freshwater nanoflagellates. Appl Environ Microbiol 58: $3715-3720$

Sommaruga R, Psenner R (1995) Permanent presence of grazing-resistant bacteria in a hypertrophic lake. Appl Environ Microbiol 61:3457-3459

Stoecker DK, Capuzzo JM (1990) Predation on protozoa: its importance to zooplankton. J Plankton Res 12:891-908

Manuscript first received: September 17, 1996

Revised version accepted: January 17, 1997 